\title{
ENTREVISTA COM MICHEL RIAUDEL
}

\section{INTERVIEW WITH MICHEL RIAUDEL}

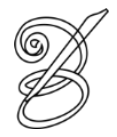 \\ Entrevistadora: \\ Clarissa Prado MARINI ${ }^{\mathrm{i}}$ \\ Universidade Federal de Santa Catarina
}

ichel Riaudel ${ }^{\mathrm{ii}}$ é tradutor de literatura brasileira na França. Doutor em Literatura
Comparada pela Université Paris X (2007). É mestre em Letras modernas pela
Universidade de Paris-Sorbonne IV (1978). É graduado em Letras modernas pela Universidade de Paris-Sorbonne IV (1977) e em Português pela Université Paris VIII Vincennes-Saint-Denis (1985). Atualmente, é professor da Sorbonne Université (ex Paris IV), onde é diretor do departamento de Estudos Lusófonos na Faculdade de Estudos Ibéricos e Latino-americanos ${ }^{\mathrm{iii}}$. É membro do Centro de Pesquisas Interdisciplinares sobre os Mundos Ibéricos Contemporâneos, o CRIMIC ${ }^{\text {iv }}$, e membro associado de outros centros de pesquisa em literatura e lusofonia.

RECEBIDO EM: 04/12/2018

ACEITO EM: 20/12/2018

PUBLICADO EM: dezembro 2018 
Clarissa Prado Marini (CPM): A partir das informações do seu currículo acadêmico, vemos que você foi professor leitor de literatura francesa em Belém entre 1979 e 80 além de ter cursado as graduações em Letras e em Português na França. Você poderia comentar um pouco mais sobre como e quando começou o seu envolvimento com o Brasil e com a língua portuguesa?

Michel Riaudel (MR): Foi em meados de 79. Uma trajetória comum a outros. Eu tinha me formado, eu tinha uma maîtrise em Letras, Lettres modernes basicamente Literatura francesa, um pouco de Literatura comparada e eu não tinha nada, nenhum vínculo com o Brasil. Não estudei português (nem espanhol). Na época, os rapazes tinham que fazer o serviço militar e tinha uma oportunidade de escapar ao quartel que era conseguir uma vaga no que se chamava de "cooperação". Eram convênios entre a França e algumas instituições. Eu me candidatei e me veio uma proposta de ser [professor] leitor na federal do Pará e então fui lá [risos]. Foi uma imersão! Eu dava aulas basicamente de literatura francesa na federal, mas também na Aliança francesa (era uma espécie de acordo entre o diretor da Aliança e eu). Confesso que na verdade as aulas mais interessantes eram na Aliança devido ao nível dos alunos. Mas ao mesmo tempo que eu dava aulas de literatura francesa, eu me formava "na marra" no português. E quando eu voltei para a França eu procurei manter e reforçar, estudar. Na verdade, demorou um tempo, porque ainda fui passar dois anos na Argélia também dando aula (num liceu argelino). Eu voltei em setembro de 83 de vez e em 84 voltei à universidade para fazer uma graduação em português.

CPM: Como você enxerga a área de estudos lusófonos e mais especificamente, estudos brasileiros na França hoje? Como você enxerga o tamanho dessa área? Como que se dão as atividades?

MR: Na verdade, o que contou muito com o meu envolvimento com essa área se deu fora da universidade porque a partir de 84, com um pequeno grupo de amigos nós lançamos uma revista cujo projeto evoluiu e o nome também, uma história que durou mais de 20 anos. E rapidamente (em 2 ou 3 anos) o projeto que era de uma revista bimestral com dossiês temáticos, se tornou uma coisa entre revista e boletim mensal. De "Braise" passou a se chamar "Infos Brésil". Uma 
revista que foi crescendo, se ampliando, e que ocupava metade do meu tempo e me obrigava ou me estimulava a manter relações com tudo que era brasileiro em Paris. Porque a revista tinha uma função de informar o que existia de livros, exposição, cinema, música, situação política, enfim. Foi também através dessa revista que eu comecei a contribuir um pouco numa área que tem mais a ver com a academia, com a universidade. Então para voltar à sua pergunta eu vou responder a partir dessa experiência da revista e chegar à presença mais universitária do português. Bom, curiosamente a revista foi lançada em maio de 84 que é um período de virada para o Brasil porque o processo de transição já estava bem avançado, era o ano das Diretas Já, uma mobilização civil muito forte, eleição do Tancredo, aquele episódio Tancredo-Sarney e isso tinha um certo impacto na França porque o Brasil estava presente muito através dos exilados (quase todos voltaram em 80). Antes de ir para o Brasil eu encontrei com exilados para entender um pouco a situação (eu tinha alguns amigos que tinham relações). E justamente nas conversas se falava da anistia, ainda não se sabia muito bem qual era o contorno, não sabia se eles iam poder voltar ou não. Mas toda essa gente acabou voltando, com algumas raras exceções. Existia uma atividade de solidariedade em relação ao Brasil, à situação da ditadura, enfim, era uma das presenças, digamos, do Brasil na França nos anos 70 e que foi um pouco minguando no começo dos anos 80. Existia até um boletim chamado "Bulletin de solidarité France-Brésil", algo assim. Eu lia, assinava esse boletim. Até propusemos de colaborar inicialmente, antes de lançar uma revista a gente queria abrir páginas culturais. E bom, era uma coisa mais política, não se interessaram e a gente começou essa experiência da Braise. Isso para dizer que (e isso a gente só percebeu depois) essa revista existiu num momento de conversão duma relação menos engajada com o Brasil e a nossa proposta era cobrir tudo, dando uma perspectiva histórica, uma complexidade às notícias que chegavam (aquelas notícias que chegam sem contexto e você não entende muito bem) com essa abordagem cultural e procurando entender um pouco o que acontecia. A revista foi lançada aproveitando um evento chamado Les Assises du portugais, um grande evento de uns três dias, que juntava a área econômica, comércio, ensino, enfim, todas as áreas, para o português (não apenas do Brasil). A iniciativa foi de pessoas do ensino, em particular Solange Parvaux, mas isso era um marco, digamos, do crescimento do português na França que começou nos anos 70. Tem uma curva ascendente do português que vai até os anos 90. Isso significa mais aulas e professores de português no segundo grau, português nos concursos (Capes, Agrégation ${ }^{v}$ ), portanto mais professores na universidade, teve um crescimento muito importante nessa fase que também correspondia a um maior interesse pelo Brasil. Atendia a presença de uma comunidade 
portuguesa muito grande na França (não sei hoje, mais na época era a maior comunidade estrangeira, em torno de 800 mil) também teve a passagem da ditatura portuguesa, a Revolução dos Cravos, a entrada de Portugal na comunidade europeia. Então mudou o quadro geopolítico em relação a Portugal e em relação ao Brasil. Na França, entra em 81 o governo socialista com bastante interesse pelo Brasil, então é dentro da universidade e do segundo grau e fora. 86 a 88 foram proclamados anos Brasil-França, três anos, com uma imensa manifestação de lançamento, com música, vieram os maiores cantores, foi uma farra, Caetano, Chico, Milton, Gal, Bethânia, Paulinho da Viola, etc., um cartaz incrível. Bom, depois continuou. E na área de literatura tivemos uma primeira manifestação, um primeiro evento que depois era o começo de uma sequência chamada Les Belles Etrangères, que era promover a literatura de um país ou de uma região. O primeiro país a ser homenageado foi o Brasil. Foi em 87, junto com o Salon $d u$ livre. Uns trinta escritores convidados, vários encontros na $\mathrm{BPI}^{\mathrm{vi}}$ de Beaubourg e outros espaços. Vieram nomes na época importantes como Ferreira Gullar, Rubem Fonseca, João Ubaldo, obviamente Jorge Amado, enfim, vários. Final de 70 a Anne-Marie Métailié cria uma editora nos primeiros tempos bastante voltada para o Brasil. No decorrer dos anos 80 ela se 134 associa a uma pessoa que foi muito ativa: Mário Carelli, para criar a primeira coleção de literatura brasileira na França. Esse movimento vai se inverter a partir dos anos 90. Então para responder a sua pergunta (desculpa essa demora) [risos], para responder à sua pergunta "como está a área hoje", o português está recuando em todos os níveis no plano do ensino. No segundo grau, nas medidas de economia, redução da diversidade de línguas, o português está na primeira linha das línguas fragilizadas. O inglês não corre risco, o espanhol cresceu muito, (pelo menos até uma época recente) ocupou o lugar que era o lugar do alemão, mas o alemão se mantém por motivos políticos. O que estou desenhando também é que essa área da cultura apesar de ter uma certa autonomia, ela é muito permeada pela situação política e pelos interesses políticos, existe uma diplomacia cultural. Por exemplo, essas Belles étrangères para a literatura brasileira cruzam outros interesses para o Brasil, comerciais etc. Não digo que hoje não existam esses interesses, mas de fato a América Latina não é mais uma área prioritária. Temos que pensar isso. A situação da América Latina nos anos 50, 60, não é a de hoje. Outras regiões concentram mais a atenção dos políticos e dos recursos que eles colocam à disposição. Então o português de modo geral está recuando bastante no segundo grau e na universidade. E essa é uma preocupação nossa. Talvez em Paris não se sente muito isso, mas quando fui contratado em Poitiers em 2009, existia uma graduação que rapidamente fomos fechando, na verdade. Poitiers já não forma alunos em português numa graduação específica e de tipo tradicional, o que 
chamamos de LLCER. O português entra numa composição com outras línguas, é diferente, mas você não tem o número de horas suficiente para formar um aluno em todas as áreas do português. E um termômetro disso é a redução do número de professeurs: hoje somos 7 professeurs de português na França. Bordeaux tinha, não tem mais, Poitiers tinha, não tem mais. Todo o sul da França não tem. Lyon não tem mais. Aix-Marseille não tem, nem Nice. São três em Paris (com Nanterre), uma em Rennes, outro em Clermont-Ferrand e duas em Montpellier. Pronto, esse é o quadro. Professeur é quem orienta, quem pode orientar. Ou quem tem HDR ${ }^{\mathrm{vii}}$, habilitação. Mas também não são muitos que têm habilitação. Então, você tem que pensar no global, porque uma coisa que eu acho que afeta muito é a falta de vaga nos concursos (Capes, Agrégation). Na verdade, há anos não tem uma Agrégation, tem às vezes uma Agrégation interne para os que já são professores no segundo grau. Mas o Capes e a Agrégation, mesmo dois três cargos no final, estimulavam um aluno a fazer uma graduação, um mestrado, etc. Era uma perspectiva profissional, bem ou mal. A redução do número de professores no segundo grau (é uma posição política, economia a curto prazo) faz com que não tenha tanta necessidade de contratar, de abrir concurso, de abrir vaga e todo o conjunto vai sofrendo com isso. Hoje, ser professeur, maître de conférence, de português significa também ser militante além de professor. Defender a literatura, etc. E a literatura brasileira se beneficiou de muitos impulsos dessa diplomacia cultural. 87, depois 98, quando o Brasil é convidado na Feira do Livro de Paris, 2005, o ano do Brasil na França, 2015, Brasil convidado de novo na Feira do Livro. Esses momentos, na verdade, estimulam as editoras, porque elas sabem que a imprensa vai dar um destaque. Até 2006 eu acompanhei pela revista a produção, eu fazia um balanço anual do que tinha sido traduzido, etc. Então eu tinha essa visão. Eu podia dizer desde os anos 80 como ia crescendo a produção editorial em relação ao Brasil. Estou chutando números, de uma média de 50 traduções, passamos em 98 para 100 traduções. Mas daí ou a editora vende ou não. Se não vender, não continua. Passadas as verbas, os incentivos, e as editoras tem um certo oportunismo compreensível, o movimento pode não se sustentar. A vocação da editora não é perder dinheiro. Você pode apostar naquilo, fazer um esforço, mas não constante e duradouro. Então tanto a nível do ensino, quanto na presença, é uma coisa relativamente frágil. É como uma editora tem acesso a produção brasileira, por exemplo? Tem que ter leitor, tem que ter gente que lê. Não é evidente. 
CPM: Era uma das minhas próximas perguntas: qual é o espaço da literatura brasileira França nesse sentido da abertura por parte das editoras para receber a literatura brasileira traduzida? E como é a recepção da literatura brasileira na França?

MR: Em 2004 (antes do ano do Brasil na França, que foi um grande momento em termos de realizações, extraordinárias, de grande qualidade), me chamaram para ser assessor/conselheiro justamente na parte de literatura e eu vi um pouco como funciona, as reuniões, os programas de ajuda e tal. Teve uma época em que se você perguntava para as pessoas o nome de um escritor brasileiro, tinha o Jorge Amado. E alguns achavam péssimo por ser o Jorge Amado, por que achavam muito exotizante, enfim. A questão é que hoje se você perguntar quem eles conhecem de escritor brasileiro eu não garanto uma resposta. Com todas as limitações e não quero entrar nos méritos, mas Jorge Amado teve essa função de encarnar a literatura brasileira e ele ajudou outros escritores a entrar João Ubaldo, Moacyr Scliar porque ele era ligado ao tio Carlos Scliar. Às vezes um prefácio, uma página para ajudar e tal. E hoje, enfim, acho que tem interesses diversos das editoras, mas é muito difícil para as editoras. É corajoso. E não basta verba. Às 136 vezes um livro todo financiado não é aceito pela editora porque ele acha que não acrescenta nada ao catálogo e vai ser mais um "pepino" do que qualquer outra coisa. Às vezes uma verba para tradução não basta para incentivar. Não tenho a explicação exata, mas eu sei pela experiência que se você organiza um evento com um autor hispano-americano você tem um público, mas se você organiza alguma coisa com um escritor brasileiro, não está garantido. Eu fiz essa experiência em Lyon e Marselha em 2005 quando participei de eventos só com escritores brasileiros e tinha um público muito reduzido. Talvez não tivesse o trabalho suficiente de divulgação, mas tem uma comunidade, tem a comunidade, tem os professores, etc, que não exista para o Brasil. É pouco, pouquíssimo. Então é claro que se continua traduzindo. Eu não acompanho tão de perto quanto na época da revista, mas eu vejo o que sai. No geral eu acho que é muito difícil para uma editora. Clarice Lispector é um pouco diferente, sendo um carro chefe das Éditions des femmes (o que não tira o mérito). Agora, por exemplo, a Métailié deixou de publicar brasileiros durante uma época sendo que um dos primeiros livros que ela publicou foi $O$ que é isso, companheiro? do Gabeira. Tinha essa coleção Machado com todos os grandes romances a partir do Brás Cubas. Mas em 2005 quando ela arriscou em Tabajara Ruas, Lya Luft, Ruffato (também sem entrar na questão da qualidade das obras) enfim, ela não continuou. Eu não perguntei diretamente, mas não continuou por quê? Porque não vendeu. Entende? De vez em quando ela publica. Por exemplo o Bernardo Carvalho, mas ele morou aqui, sempre vai 
ter uma recepção, um artigo no Libération, algo que garante uma presença. Tem outra coisa, que na verdade as editoras não divulgam os números de vendas ou mentem porque não querem dizer que vendem pouco.

CPM: Para contextualizar a leitora ou o leitor dessa entrevista sobre a sua trajetória como tradutor, cito que você traduziu livros de autoria de Guimarães Rosa (O burrinho pedrês), Milton Hatoum (Órfãos do Eldorado, Nas asas do Condor e Cidade ilhada), Luiz Schwarcz (Linguagem de Sinais e Discurso sobre o capim), Modesto Carone (Resumo de Ana), José Almino (O motor da luz), Ana Cristina Cesar (A teus pés). Traduziu também poesia de Mário Faustino, Manuel Bandeira, Hilda Hilst, Adélia Prado e da Ana Cristina Cesar além de outros textos de Clarice Lispector, Oswald de Andrade, Haroldo de Campos e João Cabral de Melo Neto. Como começou a sua carreira de tradutor efetivamente?

MR: Quando voltei no final de 1980, bom, foi um banho, uma experiência muito forte e eu queria passar, transmitir as coisas que me encantavam bastante poesia, etc. (e o projeto da revista foi isso também). Na revista teve época que sempre tinha um poema, um exemplo foi que eu traduzi a “Missa do Galo” na Braise (deve ser uma péssima tradução, mas enfim). Na época eu tinha uma motivação pessoal. Depois traduzi algumas coisas para alguns catálogos, foram as primeiras traduções pagas. E esses livros, a maior parte na verdade, eu apresentei para a editora. Por exemplo na época em 2005, o Modesto Carone $O$ resumo de Ana (um belo livro, muito bonito) eu apresentei para a Anne Lima das edições Chandeigne que gostou e apresentei junto $O$ resumo de Ana e $O$ motor da Luz. $O$ motor da Luz ela não gostou tanto, não queria publicar. E a Chandeigne teve essa iniciativa de criar uma coleção de poesia começando pela Ana Cristina Cesar (assunto de meu doutorado). Bom, a Ana Cristina foi um fracasso editorial, eu acho que as edições reconhecem o valor poético da Ana Cristina, tinha uns colegas que consideravam ela como uma poetisa de terceira categoria, então não facilitou. Bom os canais são poucos e se os canais não funcionam, daí é difícil.

CPM: Normalmente você propõe as obras para as editoras ou teve alguma que foi um convite?

MR: No caso do Resumo de Ana foi, no caso de outros não. O Guimarães foi uma proposta da Anne Lima. O Milton, eu venho traduzindo Milton há um tempo (desde o primeiro volume eu estava a fim traduzir o Milton), eu traduzi contos, mas romance foi só a partir do Órfãos do 
Eldorado. O Luiz Schwartz, acho que foi o Milton que me indicou. O motor da luz eu batalhei. $\mathrm{Na}$ verdade, foi desastroso pois a editora estava indo à falência, eu não sabia, acho que foi uma forma de recuperar verba, a editora nunca me pagou a tradução, mas fiquei mais triste pelo livro mesmo, cuja promoção ficou totalmente prejudicada. É interessante, voltando a experiência de 2005: a BPI lá no Pompidou queria organizar uma noite com autores, me consultaram, mas eles queriam (antes de qualquer consulta) o Chico Buarque. Só que ele concentrou a promoção em uma semana: agenda cheia, todos os jornalistas queriam entrevistar o Chico Buarque, então durante uma semana ele não parava de dar entrevista e o Chico não gosta dessas coisas. Todo mundo queria Chico Buarque, qualquer festival queria Chico Buarque. Isso é a mídia, ela amplifica os fenômenos, um sucesso vira uma coisa enorme e os outros não existem. Eu lembro uma vez, uma jornalista da RFI me entrevistou (porque tinha que ser em português) sobre o autor francês Michel Houellebecq, ele tinha lançado um novo livro e ela me pergunta "porque você acha que Michel Houellebecq faz tanto sucesso?" e a minha resposta foi “porque você está me entrevistando". Eu não sou especialista do Michel Houellebecq, mas ela queria porque queria ter uma entrevista sobre o Houellebecq. Famoso como é, ele lança um livro e todo mundo 138 quer mencionar o Houellebecq, entende? Porque sabe que o colega do outro suporte vai falar do Michel Houellebecq e como ele vai deixar de falar do Houellebecq? É uma coisa um pouco maluca. Não sei se isso é especialmente de hoje, mas existe um efeito de lupa. De repente o sucesso atrai o sucesso. Como você chega ao sucesso é outra questão, mas uma vez instalado, é muito difícil de desvencilhar disso. Na verdade, eu acho que uma posição como a minha (e de outros), eu acho que você tem que tentar (o que não é o meu temperamento, mas eu tento) pensar táticas, estratégias, mercado, etc, no mínimo ter um olhar um pouco distanciado para analisar tudo isso e também analisar a questão da qualidade. Uma vez, por exemplo, eu estava na organização de uma antologia de poetas lusófonos, com um terço do volume sobre o Brasil, e eu não tinha muito controle de quem ia ser selecionado e vieram nomes que eu achava que nunca deveriam estar nessa lista e eu me retirei como organizador. Acho que tudo bem, outras pessoas podem defender, mas eu não vou abrir mão de certos critérios de qualidade. Posso estar errado na minha avaliação, mas preciso assumir. Acho que essa função que o Berman fala de "translation" para falar de uma coisa maior que a "tradução", a tradução é uma face da translação. O tradutor é um pouco um agente de translação também nessa questão de selecionar. Eu não traduziria um autor de que eu não gosto. Primeiro porque eu acho que daria uma péssima tradução. Acho que você tem que bem ou mal, certo ou errado, você tem que ir se identificando com o que você acha que é o texto. Você ocupa o lugar do autor. É claro que é uma ilusão. Vai 
acontecer um encontro sobre a nota de rodapé e eu fiquei pensando sobre o que eu ia dizer no evento. Conversando com uma colega, fiquei pensando que na nota de rodapé, está escrito "NdT", mas quando você escreve uma nota de rodapé você deixa de ser o tradutor, você não é mais um tradutor, você é um comentador, mas não é mais um tradutor.

CPM: Na literatura?

MR: Não, qualquer coisa. Na verdade, uma nota de rodapé de tradução não é um trabalho de tradução porque um trabalho de tradução é justamente ocupar o lugar do autor.

CPM: É resolver dentro do texto?

MR: É resolver dentro do texto. Em nome do autor. Então quando você redige uma nota você deixa de ocupar esse lugar, você ocupa o lugar de fora, explicando, etc. Enfim, não digo que é proibido, seria idiota dizer isso. Mas digo isso só para pensar. E isso te ajuda a pensar o que é a tradução também. Por isso que eu acho superlegal esse tema (da nota do tradutor) porque na verdade faz pensar sobre a tradução. Lembro daquela belíssima imagem da Ana Cristina no final de Luvas de pelica em que sai do palco e deixa a luva no respaldar da cadeira: a luva é a imagem do texto para a Ana Cristina. Você enfia sua mão na luva onde antes tinha a mão do autor. Com todos os limites, claro que você não é o autor, enfim. Você pode criar uma ilusão de. A lógica é essa.

CPM: Falamos um pouco da trajetória, mas agora gostaria de falar da sua tradução mais recente, La ville au milieu des eaux (2018) tradução do livro de contos A cidade ilhada (2009) de Milton Hatoum. Foi lançado há dois meses apenas (setembro de 2018). Para dar um exemplo de uma tradução sua e aproveitando que essa acabou de ser publicada, você poderia comentar um pouco essa tradução? Comentar o título talvez e algumas escolhas de tradução para falar um pouco da sua prática.

MR: A questão do título às vezes é simples e às vezes é complicado. Por exemplo, Órfãos do Eldorado é relativamente simples. E nem sempre o tradutor decide sobre o título. E eu não acho ruim, porque eu acho que o título tem uma importância editorial, é normal o editor ter uma opinião sobre o título. E eventualmente uma opinião que ele vai impor ao tradutor. Eu confesso 
que "Cidade ilhada", é complicado em francês encontrar uma solução e eu deixei de lado essa questão do título até chegar no conto da "Casa ilhada". Me veio "au milieu des eaux", achei que cabia, o Milton ainda ficou hesitando, sugeriu outras possibilidades. Bom, eu entreguei a tradução com esse título e acabou ficando. Não acho um título ruim, porque diz um pouco, Manaus não deixa se ser importante (não é o único lugar do livro, longe disso, mas enfim). No caso do $O$ burrinho pedrês, a coisa foi um pouco mais complicada porque inicialmente quando a Anne Lima me convidou para traduzir O burrinho pedrês. Você viu a edição? É linda! Posso dizer porque não tenho nenhuma responsabilidade sobre a edição [risos]. Ela é muito bonita. Fiquei muito contente de ter sido associado a essa edição. Então tinha um ilustrador, o Olivier Besson, ele foi quem levou o projeto para a Anne Lima. Ele ofereceu para várias editoras, mas acabou fazendo com Anne Lima. Então inicialmente: ilustração... burrinho... história de animais... a Anne Lima tinha pensado uma coisa para um público juvenil. E já existia uma tradução, o Jacques Thiériot traduziu todo o Sagarana e o título desse conto era "Le petit âne jaspé”. E eu lembro quando ele apresentou na Maison de l'Amérique latine (ele trabalhou com o Francis Utéza que é um grande especialista em Guimarães Rosa) então ele escolheu "jaspé” 140 por causa da pedra, "burrinho pedrês", tinha que ser algum adjetivo que remetesse à "pedra". A Anne Lima não gostava da tradução do Thiériot porque ela achava que dificultava a leitura, dificultava o texto - sem ser taxativo com a tradução do Thiériot, eu entendo o que ela queria dizer, ele força muito o francês. Então o intuito era fazer uma coisa mais legível, não simplificando o Guimarães, mas com esse alvo adolescente, digamos. Então para mim era evidente que era "le petit âne gris", uma coisa simples (inclusive tem até uma música que fala do "petit âne gris"). Mas a coisa foi se complicando um pouco, a Anne Lima viu que não podia ser uma edição juvenil porque é um texto complicado e não dava para entrar nesse nicho. Tem que pensar em que prateleira vai ser exposto o livro e daí se colocou a questão de um outro título. Teve essa proposta de chamar de "sete de ouro", "sept-de-carreau" (na verdade "sete de ouro" é mais complicado que "sept-de-carreau", mas enfim). Teve a hipótese de "le petit âne $d u$ sertão", ok. Mas eu não estava muito entusiasta com essa solução (eu gostava mais de "septde-carreau"). Mas ela discutindo com o Chandeigne, ele achava importante o "sertão" porque "sept-de-carreau" não queria dizer nada, não evocava nada. Então eles encontraram uma solução que eu acho que funciona "Sept-de-Carreau, l'âne du sertão", voilà. Eu achava que não tinha tanto "sertão" no O burrinho pedrês, o "sertão" é mais em O Grande Sertão, mas tem o "sertão" de fato. Na verdade, é o cerrado, a paisagem do $O$ burrinho é o cerrado, mas Guimarães Rosa usa a palavra “sertão". Bom, O motor da luz já comentei um pouco, mas sobre 
o título eu acho que Les Nôtres é um bom título. No caso do primeiro livro do Luiz Schwarcz, Discurso sobre o capim, a palavra capim já é complicada. Aconteceu uma coisa que talvez seja interessante mencionar que ele reescreveu o final do livro um pouco levando em conta essa dificuldade do "capim". Porque o capim tinha uma importância muito grande no final, é no final na verdade que a questão do capim vai se afirmar. Então ele reescreveu um pouco. Mas o título em francês ficou Éloge de la cö̈ncidence. São histórias de tradução que estou contando. Outra questão da Cidade ilhada é que na verdade vários desses contos eu já tinha traduzido e publicado em revistas, só que o Milton mexeu em alguns textos e eu mesmo me relendo vi que tinha umas partes que tinha que mudar nas traduções. Então, uma coisa que achava que ia me ocupar um certo tempo, na verdade me ocupou muito mais mesmo no caso de um texto que eu já tinha traduzido. Eu organizo minha página na horizontal e em três colunas: o texto em português, a tradução e anotações (na verdade, essa terceira coluna não uso muito hoje em dia), mas acho que é um bom formato que eu recomendo para quem traduz. No caso, eu tinha um texto da "Cidade Ilhada", minha tradução passada e a versão anterior que eu tinha traduzido, com as eventuais variantes do Milton. Eu tinha esses três textos. Então, era um trabalho um pouco diferente nesses casos porque tem uma certa sequência num trabalho de tradução, (você traduz, você sabe disso), a gente tem um ritmo e eu ficava um pouco perturbado quando eram esses textos. Eu tinha que conferir o que tinha mudado, cotejar, comparar. Outra questão que eu me coloquei diante do conjunto (e que eu não me colocava quando traduzia os contos separadamente) foi a questão de um certo pitoresco: eu achava que era uma discussão, sobretudo em relação a palavras regionais. A minha sorte é que eu morei em Belém, então boa parte desse vocabulário, eu conheço de lá, são palavras do norte: igarapé, cunhatã... Eu acho que o leitor brasileiro do sul estranha, ele vê uma coisa regional. Agora a questão era a dosagem disso numa tradução francesa porque daí pode parecer muito pitoresco. Você pode colocar “igarapé" e uma nota de rodapé explicando, coloca "cunhatã" e se não for "cunhatã" você vai perder o sabor regional, é uma palavra tupi, enfim. Então a gente conversou um pouco sobre isso e a solução foi encontrar um meio termo para não exagerar. Já que às vezes a tradução dá um pouco esse efeito, por exemplo, uma tradução com muito palavrão choca mais na tradução. Não sei se é minha impressão, mas eu acho que alguns efeitos se amplificam numa tradução. E tem uma outra questão é que o leitor da tradução vai achar que o tradutor errou. Essas foram algumas das questões que lembro de ter discutido com o Milton. 
CPM: Você identifica que você tenha estilo de traduzir? Algum padrão ao longo de todas as traduções?

MR: Eu não me olho muito no espelho. Não fiz essa autoanálise, mas devo ter. Sei de alguns que têm de modo marcado, o que eu não acho bom, então não gostaria de ter. Mas eu devo ter. O Thiériot é muito marcado, por exemplo. Ele começou com Macunaíma, fez uma tradução em 79/80. Ninguém tinha traduzido os modernistas. Ele traduziu os manifestos, Oswald... A primeira tradução do Macunaíma estava cheia de erros, mas era uma boa tradução porque ele casou com o texto, precisava de uma criatividade, inventividade e ele trouxe isso para a tradução. Depois teve uma segunda edição que ele corrigiu muito. Eu sei porque acompanhei todas as correções para a editora. Ficou muito melhor, mas ele já tinha encontrado o tom na primeira edição. As qualidades do Thiériot que valeram na tradução do Macunaíma às vezes prejudicaram outras traduções. Por que ele adorava "sujar" o texto, forçar na sintaxe ou introduzir gíria.

\section{CPM: Um francês com muita marca do português brasileiro?}

MR: Ou isso ou a sintaxe. Na verdade, mais a sintaxe, uma coisa brutal em relação à língua. Talvez eu não seja brutal o suficiente (se eu tentar pensar no meu estilo). Para $O$ burrinho isso é marcante. Ele vai introduzir palavras chulas. É uma opção. Voltando a essa discussão, a tradução do burrinho para mim foi muito diferente das outras, porque é um texto muito difícil de traduzir. A tradução, você faz uma primeira versão rápida e depois você peneira, é o momento mais demorado, você repassa quinhentas vezes o texto. Mas no caso do burrinho não tinha como fazer isso, porque não sai um texto assim rápido numa tradução. Essa primeira versão rápida, é útil até para ter o frescor de uma formulação (depois você corrige), nessa primeira leitura vêm à mente expressões em francês que vão servir para a tradução, etc. Mas no $O$ burrinho não tem como fazer isso porque cada palavra, cada linha é uma dificuldade, uma complexidade. Tem um parágrafo que eu passei dois dias para ter uma primeira versão. É interessante porque aí, o Thiériot não teve dúvida. É uma lista de características de boi: forma do chifre, cor, forma do corpo, etc. O Thiériot coloca a palavra em português, um equivalente francês, assim sucessivamente. Acho essa solução complicada. Mas é um momento muito difícil de traduzir. Quando eu estava traduzindo O burrinho eu traduzia até chegar numa versão que me parecia aceitável e eu ia ver as soluções do Thiériot. Várias vezes batia e daí eu pensava 
que o leitor iria achar que eu copiei, mas não, eu cheguei à mesma conclusão. Às vezes também eu recuperava uma solução dele e muitas vezes não. Eu acho que a tradução é muito diferente no espírito. Agora, com todas as discussões que eu possa ter com as opções do Thiériot, eu vi que ele fez um trabalho de tradução, não foram soluções rápidas, ele realmente fez toda uma pesquisa. É um texto superdifícil $O$ burrinho. Bom, não responde a sua pergunta, mas eu não sei se tenho um estilo. Aliás, é terrível reler uma tradução sua. Ou por não ser narcisista ou por ser muito narcisista eu tenho muita dificuldade. Por isso que eu estou um pouco apavorado de você estar com esse material todo, [apontando para os exemplares de suas traduções que eu tinha trazido comigo] parece um dossiê de promotor que vai abrir um processo [risos].

CPM: Você comentou sobre a sua comunicação com o Milton Hatoum, mas ele não é o único dos autores que você traduz que estão vivos e ainda produzindo. Como é essa comunicação? O que você pergunta? Você manda para eles lerem, eles falam francês?

MR: Depende. Eu não mandei para o Guimarães, mas ele poderia ter lido [risos]. Na verdade, uma outra etapa, que não existiu para os outros livros (e que eu deixei para o final), foi ver a correspondência que ele teve com a Harriet de Onís a respeito do $O$ burrinho porque ele dá muitas pistas e, aliás, eu tive que rever umas coisas, (inclusive esse parágrafo que citei, por exemplo) a partir da leitura da correspondência. Já a Ana Cristina é uma dificuldade porque é um texto cheio de armadilhas, um texto aparentemente muito coloquial, mas é um texto hiper elaborado e com muitas ambiguidades e não é uma só ambiguidade, na mesma palavra podem ter três, quatro possibilidades de interpretação possível. Na verdade, o meu interesse acadêmico pela Ana Cristina começou pela tradução. Eu comecei traduzindo com uma amiga, Pauline Alphen, a gente tinha sessões toda semana. E tinha horas que a gente morria de rir de ver o quão sacana ela foi na escrita e era como "olha, isso daqui é para você se virar na tradução", por exemplo essa frase, em "Fogo do final" — último poema da parte nova de A teus pés - em que ela diz assim: "Caio chutando pedrinhas na calçada, damos adeus passando a mil [...]". Você pensa que ela ou ele, essa primeira pessoa, está chutando pedrinhas, se desequilibra e cai. Mas "Caio" era na época um grande amigo dela, Caio Fernando Abreu, entende? São essas coisas. Esse exemplo mostra só uma ambiguidade, mas às vezes são várias possibilidades. Você está numas areias movediças o tempo todo. Bom, esses são dois mortos que eu tive que imaginar ou me valer dessa correspondência que é valiosa. Como eu estudei muito a Ana, eu acho que sei um pouco dos vieses dela. Os outros, bem ou mal, quando tenho dúvidas eu consulto e dou 
a tradução para relerem. Já troquei mensagens com o Luiz Schwarcz. Com o Milton eu tenho uma certa liberdade, acho que com todos, com o José Almino, com o Modesto Carone. Com o Milton nesse último livro, por exemplo, eu mandei meu arquivo que tem português e francês, mas daí ele me pediu para mandar só em francês (sem o português do lado) para ler contínuo. Tem duas historinhas dessas conversas com tradutores. Uma foi justamente um encontro com o Milton para uma revista (já faz muito tempo) e teve uma hora que eu temi que estava errado no original, uma questão com as palavras "descendentes" "antecedentes" e eu escrevi para o Milton e ele disse que não, que era aquilo mesmo, e eu insisti, e a resposta dele foi dez: "olha, quer saber, escolhe você” [risos]. O autor sabe que a tradução vai ser outra coisa, vai ter sua vida própria, inclusive com equívocos, e tudo bem. Eu nunca fiquei nessa situação, mas o tradutor é que tem que ter a última palavra, o tradutor é que assina. Ele não pode ser mandado pelo autor. Eu não me lembro de nunca ter ficado nessa situação. Nesse caso eu acho que Milton estava certo, era uma tolice minha. Mas também liberou a relação de certa forma. A outra história foi com $O$ Resumo de Ana, aconteceu outra coisa. Tinha um erro em português, um lapso, superinteressante porque era uma questão do parentesco do narrador com outra

144 personagem, esta relação estava errada no texto. Estava errada porque revelava algo da presença do próprio Modesto Carone no texto. Ele fez uma confusão na hora de escrever. Eu falei com o Modesto (era uma comunicação um pouco complicada não tinha e-mail nem fax, era por telefone), eu falei e ele concordou que estava errado. Mas daí o que você faz? Corrige ou restitui o lapso? Eu acabei corrigindo para a versão francesa com o acordo do Modesto. Talvez um outro tradutor pudesse ter optado pelo lapso, mas a questão é que o leitor poderia pensar que foi erro do tradutor (não foi minha única motivação, mas uma delas).

CPM: Muito interessante poder falar com o autor.

MR: Sim, isso é fundamental. Mas sabendo o lugar de cada um. O autor é o mais importante. Mas na hora da tradução, quem assina é o tradutor.

CPM: Você traduziu poesia, romances, contos, quadrinhos (a adaptação de Dois Irmãos para quadrinhos). 
MR: Foi muito legal a experiência com quadrinhos. Traduzi a adaptação de Dois irmãos e depois a mesma empresa me solicitou para outros dois, um para um público de 12 anos, A turma da Mônica e Bidu, que era uma coisa muito mais infantil e daí muda bastante, quase não tem texto. No caso do Dois Irmãos não.

CPM: Era ainda bem colado no romance?

MR: Na verdade, o Dois Irmãos eu traduzi com o PDF, os quadrinhos não tinham sido lançados no Brasil, o livro, o álbum ainda não tinha sido efetivamente editado, ainda estava no PDF. Foi uma tradução muito especial, a primeira vez que traduzi quadrinhos. Eu não tinha sido o tradutor do romance. Então, eu estava com o PDF dos quadrinhos, o romance do Milton e a tradução francesa do romance na mesa. E eu vi rapidamente que eu precisava do romance do Milton. O trabalho dos gêmeos que ilustraram é maravilhoso, o que eles fizeram é uma coisa extraordinária. Mas eles mudaram um pouco a sequência da história na adaptação, e para o texto, quase recortaram frases. O desenho vinha não ilustrando, mas completando o sentido. Então eu precisava às vezes do contexto desse trecho para entender melhor. Eu precisava ir na fonte. E fazendo esse trabalho eu vi que algumas vezes eles erraram na transcrição, então eu ajudei a corrigir a versão original antes de ser impressa.

CPM: Quais são as maiores diferenças de tradução entre esses diferentes gêneros literários? Ou talvez completando a pergunta: Você também é tradutor de textos não literários (artigos, ensaios, manifestos) mesmo que não seja a maioria das suas traduções. Quais diferenças entre a tradução de literatura e não literatura?

MR: Eu não gosto, na verdade, se é um texto sem graça. Já traduzi textos meio ensaísticos do Milton, traduzi um ensaio do Cabral superlegal. No caso deles, é diferente. Tradutor não é a minha profissão. Eu tenho que gostar do texto. Porque na verdade é um casamento, você vai viver meses com o texto, vai ler mil vezes e o texto tem que resistir. Eu acho que nunca traduzi teatro. Quer dizer, fiz um curso a distância por escrito e tinha uma parte que era um exercício de tradução e análise. Foi algo de uma página do Nelson Rodrigues. Bem, cada gênero é um desafio. Eu digo que uma das coisas que mais achei difícil no $O$ burrinho foram os aboios, aquelas chamadas dos bois, porque você tem que inventar alguma coisa. Não é um léxico 
estabelecido. Nunca fui boiadeiro, enfim. Eu procurei se existiam equivalentes em francês. Mas aboio no Brasil é um canto, na verdade, na França talvez tenha também, mas não vi, não encontrei nada registrado e então tinha que inventar. Lembrei disso agora pensando no último quadrinho que eu traduzi, o Bidu, porque era um texto muito simples, mas era uma linguagem para crianças com muitas onomatopeias. No caso do Dois Irmãos tinha uma regra da editora que era não traduzir, o editor era uma pessoa muito bacana e ele me disse que a regra era essa de não traduzir. Esses "Slash", "Paplam"! Eu tinha até traduzido às vezes, sugerido uma tradução, mas soube depois que existia essa regra da editora. Essas onomatopeias de quadrinhos são interessantes porque às vezes é a própria palavra que já existe, mas se torna onomatopeia.

CPM: Pensando mais a partir do mundo acadêmico você que é professor, orienta trabalhos em tradução, é pesquisador, mas é também tradutor. Como você vê a relação entre teoria e prática de tradução? Tem algum título ou autor de teoria da tradução que impactou na sua trajetória?

146 MR: Impactou o Antoine Berman, porque ele é genial. Impactou também na questão de que (eu não tenho tabu de vocabulário), quando ele se recusa a usar a palavra "teoria" dizendo que é uma prática, uma reflexão, eu assino embaixo. Teoria é uma palavra cômoda, mas não se trata disso. Na verdade, a reflexão sobre a tradução que não é apenas dar um curso de tradução (eu adoro dar aula de prática de tradução), é outra coisa, é pensar em outro plano. Eu acho que já explorei pensar a tradução, no caso da Ana Cristina, como o motor da criação poética, na verdade a minha tese é de que a questão da tradução é fundamental no processo criativo da Ana Cristina, nessa dimensão da criação poética. Na dimensão de um paradigma de conhecimento, indo para o uso que as outras disciplinas fazem da tradução, a Filosofia, a Antropologia, a Sociologia, no caso do Michel Serres, da turma da Sociologia da Tradução, Michel Callon, Bruno Latour, ou Eduardo Viveiros de Castro, ou François Jullien, Barbara Cassin. São três direções. Uma coisa que tentei formular foi aproximar o processo tradutivo da metonímia, em vez de pensar em metáfora, pensar no processo da metonímia que eu acho que faz sentido no caso da Ana Cristina. Pelo estudo do caso da Ana Cristina eu percebi essa possível proximidade. Eu tenho um texto "Pour la traduction"viii que eu explico do meu ponto de vista porque a tradução é necessária. Nele eu começo dizendo que para se comunicar com alguém de língua estrangeira você tem três possibilidades: ou você usa uma língua franca comum aos dois, uma terceira língua, ou você fala a língua do outro (o que eu estou fazendo aqui), ou você traduz. 
Nessas possibilidades é claro que falar a língua do outro é maravilhoso, mas mesmo com essa possibilidade, a tradução ainda é importante e faz sentido. E uma das coisas que eu acho justamente bom da tradução é você estar dentro. Não tem como você estar fora, não pode olhar de cima, de fora. Você está dentro do aquário, não pode olhar de fora o aquário, uma hora você é peixe. Daí a formulação do Berman, você pode pensar a sua situação, você pode refletir, mas você não pode teorizar dessa position de surplomb porque é absolutamente impossível. Não é nem proibido, é impossível. É possível saindo da sua situação de tradutor. Escrevendo sei lá, que o autor escreve mal, que eu enquanto tradutor ajudei a melhorar, essas bobagens que a gente lê ou que a gente escreve. Você tem um poema, você traduz um poema. Em nossos contextos de tradução as diferenças culturais não chegam a ser tão grandes. Mas você pode imaginar que um gênero não exista numa outra cultura, daí complica.

CPM: Como você enxerga o campo dos estudos em Tradução hoje na França? A gente tem os grandes autores franceses, mas o que você poderia falar do campo da Tradução na França hoje?

MR: Quando eu dava um curso mais geral da tradução (como aconteceu em Poitiers algumas vezes) eu dedicava uma parte a uma sociologia, não a sociologia da tradução do Latour e Callon, mas uma sociologia de Bourdieu, Sapiro (vendo circulações, de qual língua e para qual língua se traduz mais etc). E a França ocupa uma posição média, o inglês é ultra dominante, se traduz do inglês e menos para o inglês. No caso da França é uma situação um tanto equilibrada, não tenho dados super-recentes, mas a partir dos dados da Sapiro, mais ou menos uns $25 \%$ era de intradução e extradução, isso para dizer que a França é um dos países que tem uma posição favorável para ter uma discussão sobre tradução. E há grandes estruturações. Tem a ATLF (Association des traducteurs littéraires de France) que é uma associação muito dinâmica e importante para estruturar a profissão. Tem Arles, tem os prêmios de tradução, tem revistas (revista da ATLF, por exemplo). No meio universitário pessoas mais voltadas para a tradução. Tem Caroline Lepage com o site Tradabordo ${ }^{\mathrm{ix}}$, Jean-Yves Masson com a História da tradução. Eu fiz parte durante três anos de uma comissão no Centre national du livre, a comissão de literatura estrangeira que avaliava pedidos de verba para tradução, se reunia três vezes por ano e tinha algo da ordem de 150 dossiês para examinar em dois dias. Mas eu aprendi muito nessa comissão e essa instituição é superinteressante, por exemplo. O Centre national du livre é ligado ao Ministério da Cultura, mas tem uma certa autonomia, e trata de tudo que tem a ver com o 
livro: questão de livraria, questão de edição, de promoção de eventos. E é uma instituição que eu vi de dentro, a partir dessa comissão (existem várias comissões), essa que eu fiz parte é de tradução, tradução para o francês. Por ter visto de dentro eu achei admirável o cuidado, claro que você pode ser injusto. Mas dentro do possível há todo um cuidado para tornar o funcionamento justo e transparente e uma coisa que é interessante dessa comissão é que você não pode ficar mais do que três anos, então tem uma rotatividade, o que é importante para não instalar certos mecanismos. Mas outra coisa é que é composta por vários horizontes, a maioria dos membros são tradutores como eu, às vezes professores ou tradutores profissionais de várias línguas em função da demanda (obviamente o inglês um pouco mais representado), mas tem também alguns editores, não muitos, mas alguns, livreiros, organizadores de eventos. Eu era ao mesmo tempo ator e observador porque você vê essa tendência, por exemplo, de defender uma linha de tradução mais ousada, digamos, mais voltada às audácias da língua fonte. Porque na verdade o que se avaliava eram duas coisas: o interesse pelo livro (se ele merecia que se traduzisse) e a qualidade da tradução. Tinha um parecer e discussões, e o parecer tinha que dar exemplos quando ele criticava uma tradução. Às vezes o parecerista não estava presente, às 148 vezes era membro da comissão, às vezes não. Então sobretudo no caso de pareceres de pessoas ausentes, às vezes tinha uma dúvida e comentavam "esse parecerista tem uma visão um pouco estreita, da qual a gente está discordando", havia uma discussão e daí circulava o parecer e ia para as mãos das pessoas mais competentes naquela língua e mesmo você não falando italiano, inglês, etc, dava para ter uma opinião. E uma coisa que eu fui formulando aos poucos é que esse tipo de comissão não tem que ter uma ortodoxia de tradução. Tinha que avaliar pelos próprios critérios do tradutor. Eu sei que a estrutura tentava, os funcionários tentavam montar um dispositivo o mais justo possível (sem favorecimentos). Eu acho que é interessante ver isso. Teve uma polêmica sobre a ex-ministra da cultura do governo Macron, que antes era a dona da Actes Sud. Dentro das críticas que fizeram a ela tinha essa coisa de que o CNL teria privilegiado a Actes Sud na atribuição de verbas porque ela era ministra. Disso eu duvido totalmente. Eu não acredito, porque na verdade a comissão que eu vi nunca entrou com esse tipo de consideração, nem tampouco de favorecer grandes ou pequenas editoras. A preocupação era encontrar um ponto de equilíbrio, acionando todos os critérios possíveis. Enfim, são muitas histórias!

CPM: Muitas histórias interessantes. Muito obrigada por compartilhar! Obrigada pela entrevista! 


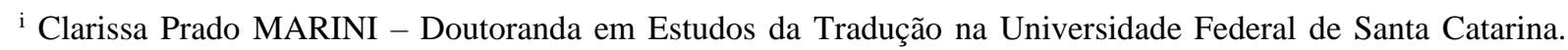
Mestre em Estudos da Tradução (2015) pela Universidade de Brasília. Bacharel em Letras-Tradução/Francês pela mesma instituição. Paris, França.

Agradeço à Coordenação de Aperfeiçoamento de Pessoal de Nível Superior (CAPES) pela bolsa do Programa de Doutorado-sanduíche no Exterior (PDSE/CAPES) com processo n ${ }^{\circ} 88881.187608 / 2018-01$

Lattes: http://lattes.cnpq.br/4474411320594145 E-mail: clarissamarini@ gmail.com

${ }^{i i}$ Michel RIAUDEL. Disponível em: http://crimic-sorbonne.fr/chercheurs/riaudel-michel/

iii UFR d'Études Ibériques et Latino-Américaines - section d'études lusophones.

iv Centre de Recherches Interdisciplinaires sur les Mondes Ibériques Contemporains (CRIMIC) / EA 2561 Sorbonne Université.

v Capes (Certificat d'Aptitude au Professorat de l'Enseignement du Second degré) e Agrégation são concursos públicos nacionais franceses para se tornar professor/a do segundo grau.

vi BPI: Bibliothèque publique d'information

vii HDR: habilitation à diriger des recherches (diploma nacional francês para doutores o que permite que pesquisadores/as sejam orientadores/as de pesquisas).

viii RIAUDEL, Michel. Pour la traduction. Non plus, v. 7, n. Especial, p. 06-18, 28 ago. 2018. Disponível em: https://www.revistas.usp.br/nonplus/article/view/149553/146662

ix http://tradabordo.blogspot.com/ 